\title{
NGFI-A-Binding Protein 2
}

National Cancer Institute

\section{Source}

National Cancer Institute. NGFI-A-Binding Protein 2. NCI Thesaurus. Code C122905.

NGFI-A-binding protein 2 (525 aa, $\sim 57 \mathrm{kDa}$ ) is encoded by the human NAB2 gene. This protein plays a role in the inhibition of early growth response protein-dependent gene expression. 